\title{
A psychological autopsy of a patient who was deceased due to medical complications associated with anorexia nervosa: A case report
}

\author{
Anoreksiya nervoza ile ilişkili tıbbi komplikasyonlar nedeniyle ölen bir hastanın psikolojik \\ otopsisi: Bir olgu sunumu
}

Şeref Şimşek ${ }^{1}$, Tuğba Yüksel ${ }^{1}$, Hüseyin Aktaş ${ }^{1}$, Süleyman Demir ${ }^{2}$

\begin{abstract}
Anorexia nervosa (AN) is an eating disorder, which is characterized by the avoidance of eating in a way that threatens the physical integrity of an individual, and trying to lose weight. It is known that the risk of mortality is high in AN. Death occurs as a results of medical complications and/or suicide. On the other hand, the exact time point of mortality becoming a risk during the progression of the disease progression is not defined. Certain predictors have been defined for mortality in AN. In this study, our aim was to present a case of a 15-year old female patient, who had died due to medical complications related to AN. J Clin Exp Invest 2015; 6 (4): 393-395
\end{abstract}

Key words: Anorexia nervosa, mortality, death, predictors

\section{INTRODUCTION}

Anorexia nervosa (AN) is characterized by clinical features including eating in small amounts, strange eating behaviors (rituals, eating in secret, hiding food etc.), controlling body weight frequently, disturbed body image, and several physical symptoms [1]. The lifelong risk of $A N$ in women ranges between $0.3-1 \%$. It has been reported that $46 \%$ of AN patients recover completely, $30 \%$ of the patients recover partially, and $20 \%$ of the patients have a chronic disease. The risk of early mortality is 10 -fold higher in AN [2]. The mortality rate in AN is higher than compared with schizophrenia, bipolar disorder, and depression [3].

It is well-known that the mortality risk is elevated in AN. Nevertheless, the timing of death during

\section{ÖZET}

Anoreksiya nervoza (AN), kişinin fiziksel bütünlüğünü tehdit edecek şekilde yememe ve kilo vermeye çalışma ile karakterize olan bir yeme bozukluğudur. Anoreksiya nervozada, mortalite riskinin arttığı iyi bilinmektedir. Anoreksiya nervozada ölümler medikal komplikasyonlar ve/ veya intihar neticesinde olmaktadır. Bununla beraber, hastalığın seyri boyunca ölüm riskinin zamanlaması belirsizdir. Anoreksiya nervozada mortalite için bazı prediktörler tanımlanmıştır. Bu çalışmada, AN'ya bağlı medikal komplikasyonlar nedeniyle ölen 15 yaşında kız olgunun sunulması planlanmıştır.

Anahtar kelimeler: Anoreksiya nervoza, mortalite, ölüm, öngörücüler

the progression of the disease progression is not defined [2]. Older age at initial diagnosis [4], alcohol abuse, and low body-mass index (BMI) are considered as mortality predictors for AN [2]. In addition, comorbid diseases such as depression, suicidal behavior, and alcohol addiction are also associated with mortality. A previous study has shown that a younger age at first diagnosis and longer duration of first hospital stay are associated with a better prognosis [5]. Even so, findings are contradictory.

In this study, our aim was to present a case of a patient, who was deceased due to medical complications related to $\mathrm{AN}$.

\section{CASE}

A.D was a 15 -year old female patient. The patient was first admitted to Dicle University Child Psychia-

\footnotetext{
${ }^{1}$ Dicle University, Medical School, Department of Child Psychiatry, Diyarbakır, Turkey

2 Dicle University, Medical School, Department of Psychiatry, Diyarbakir, Turkey
}

Correspondence: Süleyman Demir,

Dicle University, Department of Psychiatry 21280, Diyarbakir, Turkey Email: drsuleymandemir@hotmail.com

Received: 16.10.2015, Accepted: 25.10.2015

Copyright @ JCEI / Journal of Clinical and Experimental Investigations 2015, All rights reserved 
try in 2011. Her initial complaints included food refusal for approximately 1 year, looking frequently at the mirror, quick temper, and weight loss. The patient had a weight of $45 \mathrm{~kg}$, height of $1.60 \mathrm{~m}$, and had a BMI of $17.6 \mathrm{~kg} / \mathrm{m} 2$. Considering AN diagnosis, the patient was referred to a pediatric specialist. The patient was called to come for follow-up examinations, but did not show up. Future calls revealed that the patient was deceased. Detailed information was obtained following a family visit.

At the time of her death, the patient was $19 \mathrm{~kg}$, and had a BMI of $7.4 \mathrm{~kg} / \mathrm{m}^{2}$. During the previous year, the patient had lost $26 \mathrm{~kg}$. The patient was the fourth of six siblings. Her mother was 48-years old, and was an elementary school graduate. Her father was a 51-years old and construction worker, and was also an elementary school graduate. She was a wanted baby by the patient's family; she was born via vaginal delivery, and showed normal development. The patient was born in a hospital, and had normal motor and mental development. During our meeting with patient's mother, we learned that the mother was fond of her children, but the father did not give them or the home much attention. The family had financial problems, and the father was usually out of the city, offering no significant financial and moral support to the family. The father came home only twice to see his daughter when she was sick. The medical history showed that the patient started school at the age of six, and was considered to be a hard-working, smart, and easy-going student. At this time, the patient had a good relationship with her teacher and friends, and had no medical or psychological problem. The patient loved to go to school, and wanted to become a physician. During secondary school, the patient was nicknamed "bread loaf" by her friends, and became introverted. The patient fainted when she was in the second year of high school, when her mother was working as a baby-sitter. She lost weight over a three-month period (from 55 to $45 \mathrm{~kg}$ ), and the patient's mother was able to recognize the disease after these symptoms.

One month after the blackout, the patient was admitted to the clinic, where she was referred to the pediatrics department for examinations. The patient did not return for follow up examinations. As the patient continued to lose weight, she was hospitalized in the pediatrics clinic at Elazığ Psychiatric Hospital by her family, and followed up for six months. During her hospital stay, the patient showed resistance to medication, and she did not gain weight during her hospitalization. After being discharged from the hospital, the patient was taken to religious places couple of times. During this period, the patient underwent several examinations at internal medicine, pediatrics, and psychiatry clinics; however, the patient refused any treatment. The patient frequently stated that she loved her mother, and carried out her religious services until her last days. Throughout her disease, the patient did not show symptoms of binge eating, did not vomit, and did not show increased activity. The patient showed interest in and consumed low-calorie foods, such as sugar candy, fruit juice, tomatoes, cucumber, when she was hungry. The patient menstruated once when she was 15 , but did not have any subsequent period.

The patient's regard for money and frugality increased in her last year, and she started to scream when she was given food or medication. Two months before her death, the patient's aggressiveness increased significantly. The patient started to show aggressive behavior towards people in the house, and she did not permit her mother and siblings to eat. The patient did not want any visitors to the home, and told others not to tell anyone else that she was sick. During this period, the patient had a sleep disorder; she could not sleep at night, and walked around the house until morning. The patient did sleep during the day. The patient went to school regularly until one week prior to her death. The patient was taken to school by taxi during the last month. One week prior to her death, the patient was unable to get out from her bed, and frequently stated that "I will die and you will get rid of me". Three days prior to her death, large clots of blood were seen in her stools. The patient died 16 months after the initial diagnosis at home.

According to the family history, the patient's mother and father was cousin. Brother and sisters were university graduates. The patient's two siblings were in the second year of the secondary school. One of her aunts was hospitalized several times with schizophrenia diagnosis. The patient's father's sister was diagnosed with AN after the patient's death.

The patient had early-onset, and rapidly progressing symptoms. The patient refused treatment. The patient's father lived separately from his wife, and his children. The family had a significantly low income. An aunt of the patient was being treated following a diagnosis of schizophrenia. Her father's sister was diagnosed with $\mathrm{AN}$, following the death of the patient. The patient had depressive symptoms in the last two months prior to her death. 


\section{DISCUSSION}

It is known that the mortality rate is high in AN. Mortality in AN occurs as a result of medical complications and/or suicide. Low BMI [2], older age at initial diagnosis [4], alcohol addiction, and comorbid psychiatric pathologies (e.g. depression) are considered among mortality predictors for AN. Our patient had a low BMI in initial evaluation, BMI showed a rapid decrease, and the patient showed depressive symptoms in the last two months of her life. These findings are consistent with the literature. On the other hand, early onset of symptoms is not consistent with the literature, with respect to mortality risk.

Concerning the psychological condition of adolescents with AN, premorbid perfectionism, introverted nature, weak social relations, and low self-esteem appear as striking features of these individuals. Our patient was introverted, did not have many friends, and was obsessive about her studies. These findings support the literature [6]. Being on a diet is the common cause among various factors in the etiology of eating disorder [7]. The patient started a diet after being nicknamed "bread loaf" by her friends during secondary school, and experienced significant weight loss. According to psychoanalytic theory, AN is believed to emerge as a primitive defense mechanism in adolescents who cannot come to terms with the oedipal conflict [8]. In case of our patient, the neglect of the father to his wife and children supports this hypothesis.

The majority of AN cases are familial [9]. The patient's father's sister was diagnosed with AN approximately one year after the patient's death. Reports suggest that the comorbidity of lifelong Axis I psychiatric disorders ranges between $80-97 \%$ in all eating disorders. The highest comorbidity rates have been determined in mood disorders, anxiety disorders, and disorders related to drug use [10].

During differential diagnosis of $\mathrm{AN}$, primarily the general medical condition should be evaluated. The patient presented a specific behavior towards weight loss; she had a clear desire to have a slim body, and had a dysfunctional body image. Considering these findings, possible organic diseases were ruled out. Food refusal, which is seen in dementia and confusional conditions, occurs together with the disruption in cognitive functions. Given the young age and normal cognitive functions of our patient, we excluded dementia and any confusional pathology.

While significant weight loss in affective disorders, and especially in major depression suggest- ing $\mathrm{AN}$, the patient was not depressed and did not show any general reluctance when she was diagnosed. Thus, depression was ruled out. The obsession about foods in obsessive-compulsive disorder (OCD) is highly similar to AN; however, the patient did not have any obsession except for food and limiting weight gain. In addition, rituals such as collecting food and clothing are considered normal for AN, and OCD was ruled out from differential diagnosis. Food refusal, which is seen in certain types of psychosis, can suggest AN; however, these conditions are usually related to a delusion, and hallucinations can be also seen. The absence of delusion and hallucinations in our patients did not suggest psychosis. Social phobia and generalized anxiety disorder are considered as cyclical conditions. While our patient was an introvert individual, she was easy-going in her social relations and with authority figures. In addition, she did not have a generalized anxiousness. Taken together, we ruled out anxiety disorder considering these findings.

In conclusion, physicians should watch out for mortality risk in cases of early-onset AN, where a rapid decrease in BMI is seen, and depressive symptoms are present.

\section{REFERENCES}

1. Treasure J, Claudino AM, Zucker N. Eating disorders. Lancet 2010;375:583-593.

2. Button EJ, Chadalavada B, Palmer RL. Mortality and predictors of death in a cohort of patients presenting to an eating disorders service. Int J Eat Disord 2010;43:387392.

3. Ösby U, Correia N, Brandt L, et al. Mortality and causes of death in schizophrenia in Stockholm county, Sweden. Schizophr Res 2000;45:21-28.

4. Arcelus J, Mitchell AJ, Wales J, Nielsen S. Mortality rates in patients with anorexia nervosa and other eating disorders: A meta-analysis of 36 studies. Arch Gen Psychiatry 2011;68:724-731.

5. Papadopoulos FC, Ekbom A, Brandt L, Ekselius L. Excess mortality, causes of death and prognostic factors in anorexia nervosa. Br J Psychiatry 2009;194:10-17.

6. Beumont P. Clinical presentation of anorexia nervosa and bulimia nervosa: Eating disorders and obesity. Newyork: The Guilford Press, 2002;162-170.

7. Bilaç Ö, Perçinel I, Özbaran B. A Male adolescent diagnosed with anorexia nervosa: A case report. Turk J Child Adolesc Ment Health 2013;20:33-40.

8. Tomova A, Kumanov P. Sex differences and similarities of hormonal alterations in patients with anorexia nervosa. Andrologia 1999;31:143-147.

9. Bulik CM, Sullivan PF, Tozzi F, et al. Prevalence, heritability, and prospective risk factors for anorexia nervosa Arch Gen Psychiatry 2006;63:305-312.

10. Sarró S. Transient psychosis in anorexia nervosa: review and case report. Eat Weight Disord-Stud Anorex Bulim Obes 2009;14:139-143. 